\title{
Muslim Food Culture
}

Shaheed Tayob

Subject: Sociocultural Anthropology Online Publication Date: Apr 2020

DOI: 10.1093/acrefore/9780190854584.013.131

\section{Summary and Keywords}

The anthropology of Muslim food practices is a burgeoning field that promises to shift the focus away from the dominant concern with rules, conformity, and piety. Food offers an embodied and material location through which to explore the way in which religion, economy, technology, ethics, and everyday life intersect. Studying food brings into view an aspect of Muslim religious and social life that is often commented on in popular media but rarely in scholarly debate. Halal consumption, a practice rooted in intra-Muslim trade and trust, is now a global consumer market. The halal certification industry has emerged to both produce and respond to the new discursive and material context of global trade, consumption, and increasingly scientific eating habits. The new terrain of molecular halal presents opportunities and challenges for Muslim consumption. Beyond halal, food is a substance thought to produce and transmit divine grace (barakat). All-night Ramadan markets and the annual festival of sacrifice are events that draw worldwide attention. Novel phenomena include ever increasing spectacles of feasting and consumption during Ramadan and the emergence of welfare intermediaries that cater to the distribution of sacrificial animals and meat across the globe. In each instance, one obtains an insight into how a discursive and material set of practices that link religion and food are inhabited and transformed in different economic, social, and political contexts. Further research calls for further investigation of these crucial global arenas of Muslim everyday life.

Keywords: halal, certification, audit cultures, fasting, sacrifice, Islam, halal, materiality, ethics, trust, barakat

\section{Introduction}

The anthropology of Muslim food culture has emerged as a response to the overdetermination of Islam with rules, legality, and conformity. Turning to food offers an avenue for the study of Islam and Muslim society that brings economy, virtue, and everyday life into view without prioritizing ritual practice (Baderoon 2002). The serious study of food also considers the way in which the domestic, intimate spaces of home, family gatherings, and community are embodied, materialized, and memorialized in the preparation, distribution, and consumption of food (Baderoon 2002). From this view, the way in which food is prepared, consumed, and shared, as well as when and by whom, tells us much about the links between religion, social context, and processes of meaning making that once ap- 
peared too banal or unimportant for serious study. Importantly, close attention to Muslim communities, individuals, and changing contemporary contexts, through food, affords an important lens for the anthropology of Islam to move beyond the impasse between prioritizing piety versus everyday life (Fadil and Fernando 2015; Schielke 2015; Schielke and Debevec 2012). As scholars of food in other contexts have indicated, studying food as material culture reveals important links between family, intimacy, economy, and religion (Mintz and Bois 2002).

Studies of food and Muslim society have shown the historical roots of food and hospitality in the Middle East (Tapper and Zubaida 2001). The proliferation of medieval dietary manuals and cookbooks illuminates the connection between cuisine, healing, and religion among the medieval urban leisure class (Waines 2003). However, contemporary work has been less forthcoming about the intersection of everyday food practices and religion by Muslim communities across the world. The burgeoning field surveyed here offers a preliminary view of recent contributions, with a view toward exposing avenues for future research.

Muslim food is most readily associated with questions of taboo and dietary law. However, much less is known about the way that halal practice is embedded within Muslim networks of trade and trust. In recent decades, the practice of halal has undergone significant transformations that signal new concerns for the materiality of food production, global trade, and ethical relations. Beyond halal, food is imbued with ethical value as a medium for barakat (blessings) to be transferred, and produced. Food is intimately linked to questions of health through the Unani humoral theory of medicine, and the ingestion of Quranic verse is sometimes included as a healing practice. An overview of Muslim food necessarily opens up to the diverse array of ethical dispositions through which Muslims practice Islam.

\section{Halal: Dietary Law, Trust, Intention, and Trade}

Halal, meaning permissible, refers to food products that are declared edible and permissible under Islamic dietary law. However, the guidelines that govern halal are not fixed in time nor geographically homogenous. As historians of Islam have shown, the early Quranic prescriptions were, in fact, rather rudimentary about what constitutes halal and refer only to prohibitions on swine, carrion, and meat that has been dedicated to other Gods (Cook 1986). Other verses do implore Muslims to eat that upon which the name of God has been uttered (Qur'an 6:118). However, there appears no deliberation about when and how the name of God should be performed. Later, as Islam expanded, new elements of halal practice came to reflect regional and sectarian concerns as birds, reptiles, and crustaceans were drawn into halal (Cook 1986). With the establishment of Hadith scholarship and the development of a formalized Sharia, the procedures of slaughter were stipulated and prescribed. 


\section{Muslim Food Culture}

According to a very basic understanding, halal requires that the animal be placed on the ground in the direction of Mecca. The knife should be sharp. The tasmiya (the pronunciation of bisillah-allahu-akbar before slaughter) is recited and two arteries are severed. The animal should neither see the knife before slaughter nor should it witness the slaughter of other animals. These aspects of halal practice are attributed to the Hadith (the Prophetic traditions) and are considered best practice, rather than obligatory. Indeed, the diversity of sources, the categorization of practice into obligatory (fard) and recommended (sunnat), and the paucity of Quranic reference means that a great diversity of opinions of what actually constitutes halal continue to exist. Different groups across the world emphasize certain aspects of halal as more crucial than others. However, differences in practice are not merely evidence of personal preference or a desire for transgression. Authoritative texts are ambiguous about many aspects of the application of halal, meaning that scholarly attempts to explain Muslim practice as evidence of conformity and transgression or obligation and individualization are difficult to sustain. This becomes all the more important when different actors all profess to be practicing halal, albeit in diverse and often contradictory ways.

Two authoritative debates worth noting are the reference to the ahl-al-kitab (people of the book, who in the Qur'an refers to Christians and Jews), as well as Hadith narrations that discuss the timing of the prayer upon slaughter. For example, in Surah Maida, 5:2:

This day [all] good foods have been made lawful, and the food of those who were given the Scripture is lawful for you and your food is lawful for them.

According to this verse, the food of the ahl-al-kitab is halal. Indeed, there are contemporary commentators who have added caveats to the permissibility of the food of the people of the book (ahl-al-kitab). For example, in both South Africa and India, the ulama (legal scholars) are almost unanimous in the conclusion that modernity has rendered most people religious only by name. They therefore suggest that the waywardness of the ahl-alkitab is a sufficient cause for not accepting their food. Others argue that the slaughter would have to have been performed in the halal method (without severing the spine), with the name of God recited upon slaughter (tasmiya). Indeed, both caveats seek to limit the practice of halal within Muslim networks. However, the presence of the verse remains an important source for a liberal application of halal practice in the contemporary world.

Another highly regarded source for practice is the Hadith narration of Imam Malik. In his Muwatta, Malik compiled a list of the earliest Hadiths recorded. Two of the narrations refer to scenarios that mention the timing of pronunciation of the tasmiya. The two narrations appear in this order:

Yahya related to me from Mālik from Hisham ibn Urwa that his father said, "The Messenger of Allah, may Allah bless him and grant him peace, was asked, 'Messenger of Allah! Some people from the desert bring us meat, and we do not know whether the name of Allah has been mentioned over it or not.' The Messenger of 


\section{Muslim Food Culture}

Allah, may Allah bless him and grant him peace, said, 'Mention the name of Allah over it and eat.' Mālik said, 'That was in the beginning of Islam.'

Yahya related to me from Mālik from Yahya ibn Said that Abdullah ibn Ayyash ibn Abi Rabia al Makhzumi ordered one of his slaves to slaughter an animal. When he wanted to slaughter it, he said to him, "Mention Allah's name." The slave said to him, "I have mentioned the name!" He said to him, "Mention the name of Allah, bother you!" He said to him, "I have mentioned the name of Allah." Abdullah ibn Ayyash said, "By Allah, I shall never eat it!"

(Malik 2000, 327)

In the first narration, the prophet instructs his companions (sahaba) to eat the food of unknown origin as long as the name of God is recited before consumption. In the second narration, it was a companion of the prophet who became disgusted with the idea of eating meat over which the tasmiya may have been omitted at the time of slaughter. There appears to have been a difference of opinion regarding the timing of the tasmiya, at the time of slaughter, or at the time of consumption.

A contemporary online fatwa website gives a sense of the complexity at the heart of such a seemingly simple and straightforward issue. Islamqa.info is a website that offers readers advice on a variety of Islamic issues. In response to a question about the permissibility of the food of the people of the book, the author references the verse from Surah Maidah (The Table). However, his solution is not straightforward. First, he asserts the requirement that the meat should be slaughtered according to the halal method, and that the name of God be uttered. Second, the animal should not have been slaughtered via nonpermissible methods such as strangling or death by a blow. And third, that the animal has not been slaughtered in the name of a competing deity. Following this advice, the author then considers the case of meat where the method of slaughter is unknown. He refers to a Prophetic tradition where the Prophet ordered his companions to "Mention the name of Allah upon it and eat it" (Al-Munajjid 1997). In this discussion, we see that in the absence of proof about the timing of slaughter, halal is produced through the utterance upon consumption rather than slaughter.

Although there are fairly clear ideas of what constitutes halal, there are also authoritative avenues for practice that complicate straightforward understandings. From this discussion, the question of evidence seems to be crucial in determining whether meat is halal or not. The ruling suggests that in the absence of evidence, the recitation of the tasmiya upon consumption is permitted.

The incredibly complex discourse on halal includes particular forms of reasoning regarding the link between ritual practice, evidence, and performance, with insights into the authoritative resources upon which halal practice may draw. However, despite the density of halal discourse, Muslims in many parts of the world continue to refer to halal as if it is uniform and straightforward. In everyday life, individuals do not always query the exact interpretation of halal before determining whether to consume or not. The key to under- 
standing halal in practice therefore necessitates a consideration of the link between sin, salvation, and niyyat (intention) within Muslim networks of trade.

\section{Trust, Intention, and Intra-Muslim Trade}

In practice, the consumer of halal meat is usually not the supplier nor the actual butcher. Given the chain of responsibility necessary for the practice of halal, trust is central. A halal rule of thumb considers that supply by a fellow Muslim constitutes halal. In the event that a Muslim supplier knowingly provides a non-halal item, the consumer is absolved of sin. If both supplier and consumer are ignorant about the non-halal status of a food product, then both are exempt. Importantly, it is considered undesirable (makrūh) for a Muslim to doubt the halal status of the food of another Muslim. In the absence of clear evidence of transgression or devious behavior, halal practice is assured through the intention (niyyat) to consume within Muslim networks of trade. Niyyat as orientation, disposition, and taxonomic categorization of ritual practice in Islam (Powers 2004) thus emerges as crucial to the production and consumption of halal. Divergent interpretations of halal are often sidelined by a communal notion of trust that considers niyyat (intention) within Muslim networks of trade as central for practice.

The communally charged notion of trust that is central to the practice of halal, however, is always ripe for the emergence of sectarian conflict through the denial of the food of other groups. In a richly layered text, Freidenreich (2011) has offered an analysis of the progressive sectarian impulse in the development of medieval Islamic dietary law. However, in the absence of clear conflict or sectarian strife, signs of Muslim identity such as first names, dress, and images of sacred sites or symbols serve as signifiers of halal. Trust in halal is assured through trade and consumption with fellow Muslims, supported by a particular notion of niyyat (intention), salvation, and sin.

\section{Halal Certification: Global Trade, Cross-Conta- mination, and Food Technology}

In recent decades, developments in trade and finance have complicated Muslim consumption within Muslim-only networks. For example, it is now possible for Muslims in America to purchase halal-slaughtered Australian lamb chops from the local Walmart. Importantly, the transformation in the material conditions of trade has been accompanied by the increasing sophistication and opacity of food technology. Enzymes, flavorants, and colorings from animal sources are commonly used in otherwise innocuous household items that range from yoghurt and sweets to chocolates and even bottled water. Now, neither the purchase of meat from Muslim sources nor the consumption of non-meat items necessarily ensures halal. The complexity of global supply may evade the scope of a Muslim retailer. And the chemical composition of manufactured food products requires expert supply chain management and even DNA testing to determine the exact source of ingredients. Together, these developments have both complicated the supply of halal and given 


\section{Muslim Food Culture}

birth to a halal certification industry that seeks to assure the practice of halal on a global scale even in non-Muslim contexts (Tayob 2012). A halal certification industry has emerged that has altered but not completely suppressed the earlier practice and discourse of halal.

The halal certification industry seeks to assure the practice of halal in a global consumer market in a bid to ensure the documentary regulation and audit of halal practice on a global scale (Fischer 2016). However, it is important to recognize that the changes to halal introduced by certification amount to much more than a simple coming together of halal practice, global trade, corporate culture, and scientific testing. A closer look at the shifts entailed by the certification industry point to substantive transformations of language, materiality, and ethical practice.

Halal certification emphasizes two novel arenas of activity as risks to the integrity of halal. The first is cross-contamination, which is understood as the possibility for halal and non-halal items to come into physical contact with each other at any point during manufacture, distribution, or supply. Mitigating the risk of cross-contamination requires detailed supply chain management to ensure separate spaces, utensils, and vehicles. The second is the focus on food technology. Here the industry focuses on ingredients listing and production processes as crucial for determining the halal status of manufactured food. Food technologists and DNA tests are employed in a bid to establish material certainty over all food and even non-food items. Central to this twin development is the notion that the material certainty of halal can and should be established. Halal practice removed from Muslim networks of trade can no longer rely on surface signs of Muslim identity. Rather, the industry now emphasizes molecular certainty and supply chain management as key to the global certification of halal.

Halal is thus extended from concern with permissible animals and meat toward all items of Muslim consumption and use. The twin developments of cross-contamination and food technology necessarily require a level of expert knowledge that exceeds the scope of the individual Muslim consumer and supplier. Certification organizations comprised of scientific experts and ulama (legal scholars) conduct halal audits in a bid to regulate the emerging terrain of "molecular halal" (Tayob 2019).

The new conditions of halal consumption and trade have given rise to new opportunities, anxieties, and concerns. Malaysian Muslim consumers in London consume Malaysian-certified halal products as a way of asserting their national identity (Fischer 2008). In both France and the United Kingdom, Muslim groups argue for the right to consume halal that dovetails with consumer trends in organic and free-range labeling (Bergeaud-Blackler 2007). Also important are the ways in which the practice or contravention of halal in China is tied to global aspirations for living a middle-class consumer lifestyle (Gillette 2005). And in South Africa, certification mediates new kinds of ethical relations as certified consumption becomes articulated with personal piety (taqwa) (Tayob 2016). New research into the expansion of halal certification across the world will shed further insights on the 


\section{Muslim Food Culture}

transformations through which a predominantly local and communal practice of halal consumption enters the global consumer market economy.

However, contrary to predictions of a uniform and totalizing neoliberal transformation of halal, evidence suggests that much of the diversity and complexity of halal practice continues. Indeed, Muslims around the world continue to draw on a pre-certification notion of halal premised on intra-Muslim trade, even in global markets. The authoritative discussions on the timing of the tasmiya, the food of the people of the book (ahl-al-kitab), and consumption within Muslim networks of trade continue to serve as an important resource for ethical deliberation through which to consume. The picture is less an issue of total transformation than a series of developments and negotiations by Muslims around the world as they grapple with and profit from the new conditions of global trade and scientific food production. Here again, one is reminded of the insights of Talal Asad, that a discursive tradition "is simply a tradition of Muslim discourse that addresses itself to conceptions of the Islamic past and future, with reference to a particular Islamic practice in the present" (Asad 1986, 14). The practice of a discursive tradition refers not to blind repetition, but rather to the way in which authoritative sources and notions of the good are articulated and expressed in particular contexts.

\section{Barakat: Food Practice Beyond Halal}

Given that halal practice is assured through networks of Muslim trade, the explicit concern over halal food in Muslim majority contexts is heavily circumscribed. In fact, it is not uncommon for Muslims in majority contexts to claim ignorance about halal or proclaim it as superfluous (Graf 2016). This has led some scholars to fearful and simplistic conclusions about the invention of halal in order to make a link between fundamentalism and halal certification (Bergeaud-Blackler 2017). More important is to recognize that in majority contexts where the emphasis on halal is subdued, it is possible to observe how food features as a good that is imbued with ethical value. For example, the annual month of Ramadan and the two festivals of Id are marked by the preparation, sharing, and distribution of food. Other times of the week or year with religious significance are often marked by the consumption of particular foods. This section draws attention to some of the shared discursive and material notions of barakat as articulated through food practices by Muslims across the world. More detailed ethnographies of how the notion of barakat is practiced, transformed, and negotiated in everyday life are required in order to illuminate this central aspect of Muslim everyday life.

Barakat, as divine grace, blessing, and power, is an important notion through which ingestion and food obtain ethical value. Barakat is commonly ascribed to holy places and holy people and can be transferred to others through physical contact or pilgrimage (Jennings 1991, 547). In Morocco, West Africa, and Southern Egypt, it is held that the barakat of a holy man can be imbibed through the shared ingestion of food (Hunwick 2017; Westermarck 1933). Participants may attend a zikr, or at least share in the ceremonial food as a means of obtaining barakat (Jennings 1991, 548). ${ }^{1}$ The link between God's blessings and 


\section{Muslim Food Culture}

food may translate into a desire to engage in elaborate food preparations to mark important events such as weddings, funerals, and Id celebrations. For some scholars, the link between barakat and food is so strong as to position sharing and food preparation as a pious act (Shirazi 2015). However, as will be seen, the association of barakat to piety is limiting. Barakat, as power, grace, and blessing, is far more capacious than the notion of piety as intentional self-cultivation (Mahmood 2011). It is more useful to think about barakat as a "divine excess" that is both transferred and produced through acts of kindness, sharing, almsgiving, comradery, and good will (Mittermaier 2013, 285).

\section{Ramadan: Fasting and Feasting}

Ramadan is the annual month of fasting in the Islamic calendar that brings consumption into sharp focus. During the month, Muslims are obligated to fast from just before sunrise until sunset. According to a dominant normative understanding, fasting is considered an austere disciplinary practice through which pious subjectivity is cultivated (Schielke 2009). Practitioners are advised to control their thoughts, gaze, and words during the month. Extra prayers are performed in the evenings and Qur'an recitation is encouraged. However, Ramadan is not solely about fasting, prayer, and reflection. Indeed, as scholars of Christianity have noted, fasting, feasting, and feeding are all intimately related (Bynum 2013 , 277). Islam is no exception. Each year, global news outlets feature photo articles documenting the elaborate evening meal preparations and all-night markets that are a common feature across the Muslim world (ABC News 2018). Indeed, the repeated injunctions by religious leaders to pray more and eat less is evidence of the strong association of Ramadan with feasting, sharing, and celebration (Tayob 2017).

Appreciating the importance of food during Ramadan means returning to the notion of barakat as blessing. Ramadan is considered a month of "great blessings" that may be understood to reside in prayer, food, friendship, and trade. Ramadan is a month that witnesses an increase in "permissible" consumption, of which the largest portion is spent on food (Tobin 2013, 304). In India and elsewhere, late-night markets preparing and serving special delicacies attract thousands of visitors. The blessings of Ramadan are evident in the variety of tastes on offer. Preparing food and sharing food are key to these Ramadan celebrations and are also considered a form of righteous activity during the month (Tayob 2017, 151-175).

A popular prophetic injunction offers a reward (sawab) to anyone who feeds a fasting person the sunset meal (iftar). ${ }^{2}$ Articulating feeding as a virtuous act translates into a desire to share food with friends, neighbors, and the poor. Both piety and charity are therefore emphasized during the month (Khare and Rao 1986). This is most evident during the evening meal that marks the end of the fasting day (iftar). For many people, the satisfaction, taste, and joy of the recipient is evidence of barakat (blessings) transferred through food. 


\section{Muslim Food Culture}

Acts of gifting are always opportunities for display, status, and hierarchy (Mauss 2002). Who gives what and when are not overtly advertised but nevertheless become associated with particularly prominent individuals and families. Across the world, mosques provide iftar meals for congregations funded by nation-states, traders, and politicians. In Mumbai, certain mosques are known for serving particularly scrumptious iftar meals, regularly attributed to the generosity of the donor. Local politicians are famous for marking the month with "iftar parties" where excellent food and an A-list Bollywood guest list are regular features. The exact form of iftar celebrations is, of course, not predetermined, but depend on local contexts, political formations, and economic developments. For example, in Istanbul, the confluence between an increasingly neoliberal consumer economy and Ottoman nostalgia converge around the "iftar table" at high-end restaurants, special shopping festivals, and even fast-food outlets. There too, the hosting of iftar events is implicated in the broader economics and politics of the city (Karaosmanoglu 2010). However, to reduce these particular forms of iftar celebration to contextual economic and political developments is to ignore the longer duration view of how discursive and material practices inherited from the past are transformed and reanimated in the contemporary world.

\section{Qurbani: Sacrifice, Slaughter, Sharing}

Id-ul-Adha is another major festival of the Islamic calendar. Id-ul-Adha marks the end of the annual Hajj pilgrimage and commemorates the willingness of the Prophet Ibrahim (Abraham) to sacrifice his son Ismail (Ishmael) in lieu of God's orders. At the last moment, in exchange for Ibrahim's submission, God placed a ram in Ismail's place. Ismail was saved and the ram slaughtered. Annually, Muslims around the world commemorate the great sacrifice of Ibrahim by dedicating a ram, sheep, goat, ox, or camel for slaughter. After slaughter, one third of the meat is reserved for the household, one third for friends and family, and one third for the poor. Clearly the practice of sacrifice is imbricated in practices of piety and submission as well as economics, market exchange, gifting, sociality, and feasting.

Actual practices of sacrifice (Qurbani) differ significantly across the world. For example, during the Hajj, animals are transported across long distances to service the needs of the millions of pilgrims who visit Mecca each year. In Morocco, the significance of the sacrifice is reinforced and appropriated through official state displays of power (CombsSchilling 1990). In India, where no official state sanction obtains, the idea of sacrifice is linked to questions of care and attachment to the sacrificial animal before slaughter (Tayob 2017, 122-150). Much like in Indonesia, the practice of sacrifice is closely tied to the distribution of meat such that gifting and sacrifice are always intimately related (Bowen 1993; Mauss and Hubert 1964). However, sacrifice does not have to be performed in person, and it is increasingly common for Muslims to dedicate a sacrificial animal to a poor or war-torn region. In these instances, local religious organizations or global intermediaries, such as Islamic Relief, ensure the performance of the sacrifice and distribution of the meat in exchange for a fee. Here too, an established notion of barakat as blessing, 


\section{Muslim Food Culture}

sacrifice, and gifting is transformed in the context of a global economy of finance, poverty, and welfare.

Future research should pay attention to the way in which new discussions surrounding animal welfare, environmental sustainability, and middle-class consumer lifestyles give rise to new discursive and material articulations of sacrifice by Muslims in different contexts.

\section{Food, Medicine, and Healing}

Historically, there are close associations between food and healing. The unani (lit. Greek) medical system, practiced across the Muslim world for hundreds of years, clearly articulates a link between food, healing, and authoritative religious sources (Alavi 2008). The unani medical system is based on a humoral theory of the body combined with prophetic dietary practice. Popular products considered medicinally beneficial and prophetically inspired include dates, milk, and honey. These and similar food products are prescribed for medicinal benefits while at the same time thought to contain and transmit prophetic wisdom. Close attention to the way in which Muslims discuss, consume, and prepare these authorized and preferred food products has not been extensive and deserves more attention. Particularly interesting is the revival of unani by middle-class Muslims as an alternative to Western medical practices.

The link between religion and healing extends beyond food to include the power of Quranic verse and prayer. Richard and Nancy Tapper found that among Durrani Pashtuns, food consumption extended beyond religion to include health, honor, and magic (Tapper and Tapper 1986). In their analysis of magic, they refer to a common practice of "a mulla writing Koranic verse on a paper that is then eaten or the ink washed off and drunk" (Tapper and Tapper 1986, 73). Similarly, in Darfur (Sudan), it has been noted among the Berti Muslim group that individuals consult with specialists (faki) to have Quranic verse written onto a wooden tablet. The ink is then washed off with water and ingested (El-Tom 1985). Prescriptions include everything: "an illness, starting a business, getting involved in a dispute, setting out on a journey, etc." (El-Tom 1985, 417). Interestingly, during the 1980s when El-Tom carried out the research, he noted that practitioners in Darfur consulted manuals imported from across the Islamic world, from "Egypt, Iran, Lebanon and Saudi Arabia" (El-Tom 1985, 416).

A similar practice in South Asia involves the prayers of a holy person or family member which are then blown onto a vessel of water. The water, thus transformed into holy water, is considered powerful and offered to the ill. Also common is for visitors to a local shrine to place an empty bottle of water in front of the tomb for a period of time while prayers are performed. The bottle is then collected and taken home to be offered to a sick family member as a healing cure. Given the advent of allopathic theories of medicine, there is often skepticism about the efficacy of these traditional forms of healing. And of course, reformers are quick to judge these practices as superstitious and un-Islamic. However, as a 
healing practice, they continue as important ways in which Muslims link health, ingestion, and faith.

\section{Opportunities for Future Research}

The significance of food in everyday Muslim life is undeniable. However, to date the study of food has suffered from an overdetermination of Islam with piety. This means that notions of charity, gifting, and community, authorized by the discursive tradition of Islamic practice and thought, are sidelined. This article provides an overview of some of the avenues through which to explore the significance and complexity of food as embedded in Muslim social life.

Halal certification has in recent decades emerged as a significant global phenomenon that introduces new opportunities and challenges for Muslim trade and consumption. Understanding certification necessitates a consideration of the way in which older practices of halal, rooted in intra-Muslim trade, are transformed, displaced, or resist the new demands of certification, technological food production, and global trade. The notion of barakat is important for thinking of Islam beyond austere piety in a bid to capture much of the capaciousness and celebratory aspects of Islam around the world. However, as anthropologists, it is important to remember that the way in which barakat as blessing is deployed and articulated requires very careful investigation of the changes and shifts in society, within which practices, expressions, and food preparations are always embedded. For example, in America, food preparation and consumption by African American Muslims is intimately related to a history of slavery and the way in which that memory is valorized or rejected (Rouse and Hoskins 2004). Similarly, in South Africa, Malay Muslim food culture articulates links between gender, memory, class, and a history of slavery (Baderoon 2007; Baderoon 2002; Baderoon, 2009). The overview in this article therefore is best considered a signpost through which to investigate the particular ways in which a discursive tradition of past text and practice is articulated and materialized in different economic, political, and social contexts across the contemporary world.

\section{Further Reading}

Alavi, Seema. 2008. Islam and Healing: Loss and Recovery of an Indo-Muslim Medical Tradition, 1600-1900, 384. Basingstoke, U.K.: Palgrave Macmillan.

Asad, Talal. 1986. "The Idea of an Anthropology of Islam." Occasional Papers Series.

Washington, DC: Center for Contemporary Arab Studies, Georgetown University.

Baderoon, Gabeba. 2002. "Everybody's Mother Was a Good Cook: Meanings of Food in Muslim Cooking.” Agenda 17 (51): 4-15.

Baderoon, Gabeba. 2007. “'Catch with the Eye': Stories of Muslim Food in Cape Town.” In Imagining the City: Memories and Cultures in Cape Town, 115-131. Cape Town: HSRC Press. 


\section{Muslim Food Culture}

Fischer, Johan. 2016. Islam, Standards, and Technoscience: In Global Halal Zones, 207. New York: Routledge.

Mintz, S. W., and C. M. D. Bois. 2002. "The Anthropology of Food and Eating." Annual Review of Anthropology 31: 99-119

Rouse, Carolyn, and Janet Hoskins. 2004. "Purity, Soul Food, and Sunni Islam: Explorations at the Intersection of Consumption and Resistance." Cultural Anthropology 19 (2): 226-249.

Tapper, Richard, and Sami Zubaida, eds. 2001. A Taste of Thyme: Culinary Cultures of the Middle East. London: Tauris Parke.

Tayob, Shaheed. 2016. "'O You Who Believe, Eat of the Tayyibāt (Pure and Wholesome Food) which We Have Provided You': The Role of Risk and Expertise in Producing Certified Halal Consumption in South Africa." Journal of Religion in Africa 46 (1): 67-91.

Tayob, S. 2019. "Molecular Halal: Producing, Debating and Evading Halal Certification in South Africa." In Insatiable Appetite: Food as Cultural Signifier in the Middle East and Beyond, edited by D. Kirill, J. Hauser, and B. Orfali, 100-118. Leiden and Boston: Brill.

\section{References}

ABC News. 2018. "Ramadan 'Iftar' Meals from Around the World."

Al-Munajjid, S. M. S. 1997. "Permissibility of Eating Meat Slaughtered by Christians and Jews."

Alavi, S. 2008. Islam and Healing: Loss and Recovery of an Indo-Muslim Medical Tradition, 1600-1900. Basingstoke, U.K.: Palgrave Macmillan.

Asad, T. 1986. The Idea of an Anthropology of Islam. Washington, DC: Center for Contemporary Arab Studies, Georgetown University.

Baderoon, G. 2002. “Everybody's Mother Was a Good Cook: Meanings of Food in Muslim Cooking." Agenda 17 (51): 4-15.

Baderoon, G. 2007. "'Catch with the Eye': Stories of Muslim Food in Cape Town." In Imagining the City: Memories and Cultures in Cape Town, 115-131. Cape Town: HSRC Press.

Baderoon, G. 2009. "The African Oceans-Tracing the Sea as Memory of Slavery in South African Literature and Culture." Research in African Literatures 40 (4): 89-107.

Bergeaud-Blackler, F. 2007. "New Challenges for Islamic Ritual Slaughter: A European Perspective.” Journal of Ethnic and Migration Studies 33 (6): 965-980.

Bergeaud-Blackler, F. 2017. Le Marché halal ou l'invention d'une tradition. Paris: Le Seuil. 
Bowen, J. R. (1993). Muslims through Discourse: Religion and Ritual in Gayo Society. Princeton, NJ: Princeton University Press.

Bynum, C. W. (2013). “Fast, Feast, and Flesh: The Religious Significance of Food to Medieval Women." In Food and Culture, 3 ed., edited by C. Counihan and P. V. Esterik, 245264. New York: Routledge.

Combs-Schilling, M. E. 1990. Sacred Performances: Islam, Sexuality and Sacrifice. New York: Columbia University Press.

Cook, M. 1986. “Early Islamic Dietary Law.” Jerusalem Studies in Arabic and Islam 7, 218-277.

El-Tom, A. O. 1985. "Drinking the Koran: The Meaning of Koranic Verses in Berti Erasure." Africa: Journal of the International African Institute 55 (4): 414-431.

Fadil, N., and M. Fernando. 2015. "Rediscovering the "Everyday" Muslim: Notes on an Anthropological Divide.” HAU: Journal of Ethnographic Theory 5 (2): 59-88.

Fischer, J. 2008. Proper Islamic Consumption: Shopping Among the Malays in Modern Malaysia. Leifsgade, Denmark: NIAS Press.

Fischer, J. 2016. Islam, Standards, and Technoscience: In Global Halal Zones. New York: Routledge.

Freidenreich, D. M. 2011. Foreigners and Their Food: Constructing Otherness in Jewish, Christian and Islamic Law. Berkeley, CA: University of California Press.

Gillette, M. B. 2005. “Children's Food and Islamic Dietary Restrictions in Xi'an.” In The Cultural Politics of Food and Eating: A Reader, edited by J. L. Watson and M. L. Caldwell, 106-121. Malden, MA: Blackwell.

Graf, K. 2016. “Beldi Matters: Negotiating Proper Food in Urban Moroccan Food Consumption and Preparation." In Halal Matters: Islam, Politics and Markets in Global Perspective, edited by F. Bergeaud-Blackler, J. Fischer, and J. Lever, 72-90. London: Routledge.

Hunwick, J. 2017. "Religion and State in the Songhay Empire 1464-1591." In Islam in Tropical Africa, edited by I. M. Lewis, 124-143. New York: Routledge.

Jennings, A. M. 1991. “A Nubian Zikr. An Example of African/Islamic Syncretism in Southern Egypt." Anthropos 86 (4/6): 545-552.

Karaosmanoglu, D. 2010. "Nostalgia Spaces of Consumption and Heterotopia: Ramadan Festivities in Istanbul." Culture Unbound: Journal of Current Cultural Research, 283-302.

Khare, R. S., and M. S. A. Rao. 1986. "Introduction." In Aspects in South Asian Food Systems: Food, Society, and Culture, edited by R. S. Khare and M. S. A. Rao, 3-18. Durham, NC: Carolina Academic Press. 
Mahmood, S. 2011. Politics of Piety: The Islamic Revival and the Feminist Subject. Princeton, NJ: Princeton University Press.

Malik. 2000. Muwatta' Imam Malik. Translated by P. M. Rahimuddin. Lahore, Pakistan: Sh. Muhammad Ashraf.

Mauss, M. 2002. The Gift: Forms and Functions of Exchange in Archaic Societies. London: Routledge.

Mauss, M., and H. Hubert. 1964. Sacrifice: Its Nature and Function. Translated by W. D. Halls. Chicago: University of Chicago Press.

Mintz, S. W., and C. M. D. Bois. 2002. "The Anthropology of Food and Eating." Annual Review of Anthropology 31: 99-119.

Mittermaier, A. 2013. "Trading with God: Islam, Calculation, Excess.” In A Companion to the Anthropology of Religion, edited by M. Lambek and J. Boddy, 274-293. West Sussex, U.K.: Wiley Blackwell.

Mittermaier, A. 2019. Giving to God: Islamic Charity in Revolutionary Times. Berkeley: University of California Press.

Powers, P. R. 2004. "Interiors, Intentions, and the "Spirituality" of Islamic Ritual Practice." Journal of the American Academy of Religion 72 (2): 425-459.

Rouse, C., and J. Hoskins. 2004. "Purity, Soul Food, and Sunni Islam: Explorations at the Intersection of Consumption and Resistance." Cultural Anthropology 19 (2): 226-249.

Schielke, S. 2009. "Being Good in Ramadan: Ambivalence, Fragmentation, and the Moral Self in the Lives of Young Egyptians." Journal of the Royal Anthropological Institute 15 (1): 24-40.

Schielke, S. 2015. "Living with Unresolved Differences: A Reply to Fadil and Fernando." HAU: Journal of Ethnographic Theory 5 (2): 89-92.

Schielke, S., and L. Debevec, eds. 2012. Ordinary Lives and Grand Schemes: An Anthropology of Everyday Religion. New York: Berghahn Books.

Shirazi, F. 2015. "Sofrih and Walima: Food as Ritual in the Islamic Republic of Iran." In Women's Rituals and Ceremonies in Shiite Iran and Muslim Communities: Methodological and Theoretical Challenges, edited by P. Khosronejad, 25-40. Munich: LIT Verlag.

Tapper, R., and N. Tapper. 1986. “'Eat This, It'll Do You a Power of Good': Food and Commensality among Durrani Pashtuns.” American Ethnologist 13 (1): 62-79.

Tapper, R., and S. Zubaida, eds. 2001. A Taste of Thyme: Culinary Cultures of the Middle East. London: Tauris Parke. 


\section{Muslim Food Culture}

Tayob, S. 2012. "Consuming, Producing, Defining Halal: Halal Authorities and Muslim Consumers in South Africa." Master's thesis, University of Cape Town, Cape Town.

Tayob, S. 2016. “'O You Who Believe, Eat of the Tayyibāt (Pure and Wholesome Food) which We Have Provided You': The Role of Risk and Expertise in Producing Certified Halal Consumption in South Africa." Journal of Religion in Africa 46 (1): 67-91.

Tayob, S. 2017. "Islam as a Lived Tradition: Ethical Constellations of Muslim Food Practice in Mumbai." PhD diss., Utrecht University, Utrecht, The Netherlands.

Tayob, S. 2019. "Molecular Halal: Producing, Debating and Evading Halal Certification in South Africa." In Insatiable Appetite: Food as Cultural Signifier in the Middle East and Beyond, edited by D. Kirill, J. Hauser, and B. Orfali, 100-118. Leiden and Boston: Brill.

Tobin, S. A. 2013. "Ramadan Blues: Debates in Popular Islam during Ramadan in Amman, Jordan.” Domes: Digest of Middle East Studies 22 (2): 292-316.

Waines, D. 2003. “'Luxury Foods' in Medieval Islamic Societies.” World Archeology 34 (3): 571-580.

Westermarck, E. 1933. Pagan Survivals in Mohammedan Civilisation. London: Philo Press.

\section{Notes:}

(1.) Zikr/dhikr (Arabic: "reminding oneself," or "mention") is a practice of reciting the names of God, specific ritual prayers or Quranic verses, in a repetitive and often rhythmic manner in order to achieve closeness to God. A zikr event is often held on the occasion of the celebration of the death of important saints, the birth of children, as well as weekly on Thursday evenings.

(2.) The prophetic injunction is as follows: "Whoever gives iftaar to one who is fasting will have a reward like his, without that detracting from the reward of the fasting person in the slightest."

\section{Shaheed Tayob}

Stellenbosch University 